\section{The Influence of Obliquity on Europan}

\section{Cycloid Formation}

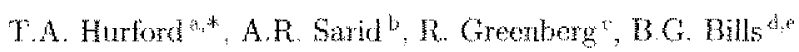

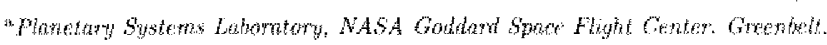
Mo sam

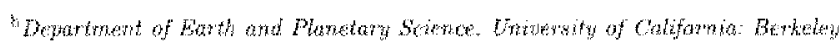
Berteley. CA gron

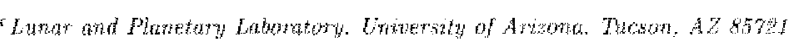

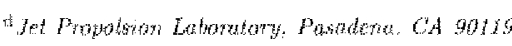

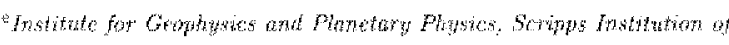

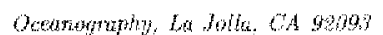

\section{A.bstract}

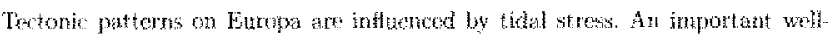
recognizad componont is atsociated with the obital encentricity, which podues a

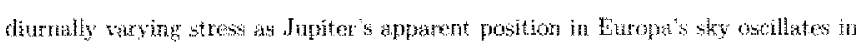

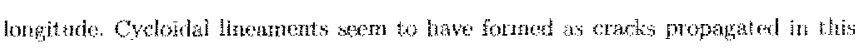

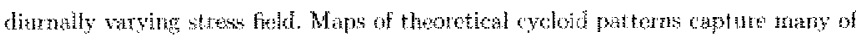

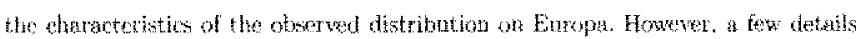

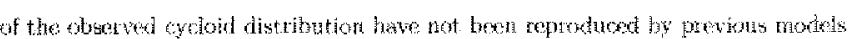

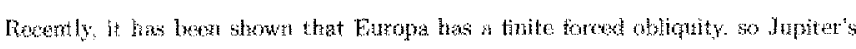

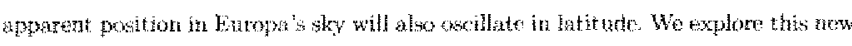

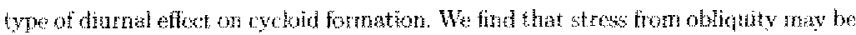

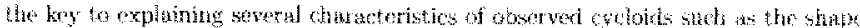

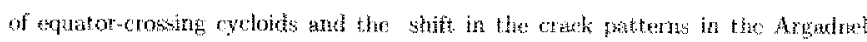

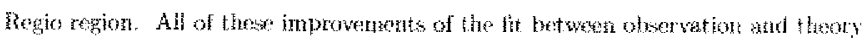

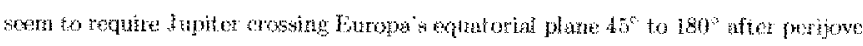

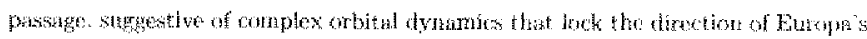
perrenter with the diretion of the ascending node at the the these efacks wow tormetil.

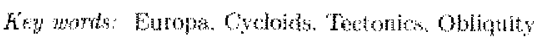

\section{Introrluction}

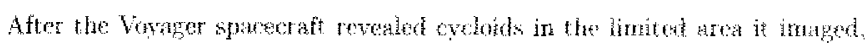

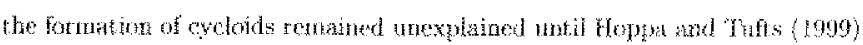

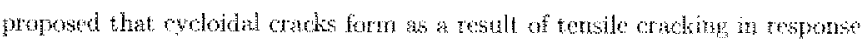

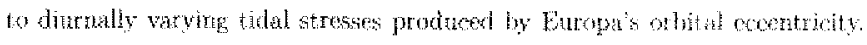
In their model cyctoid-shaped encks form in the foltewing way then the

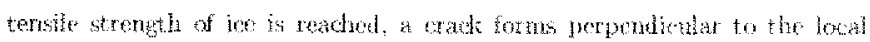

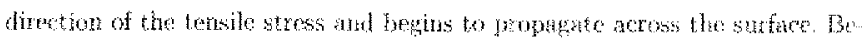

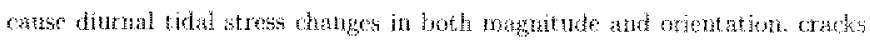
propagate acows an ewer-banging stress fold Thus propagation can follow

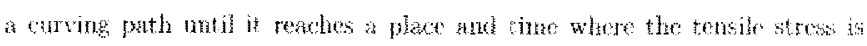
irsuffecent to continue the promgation. The propkgetion fornains alomat

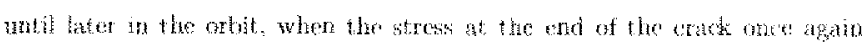

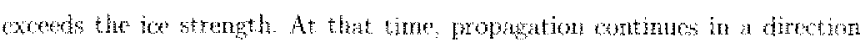
perpenticular to the rew arintution of terisile stress. The shaye of the crodk

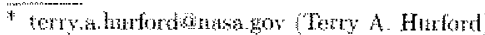




\section{The Global Picture of Cycloid Formation}

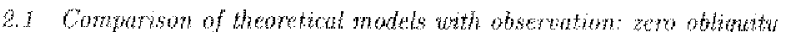

Fig. 1 shows maps of idealized cydods that would form at lotatints areos

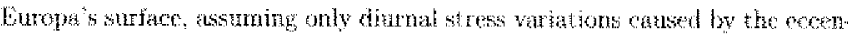

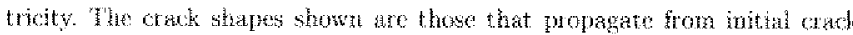

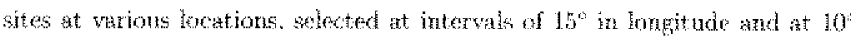
interwals in hattude between $10^{\circ}$ and $70^{\circ}$ in the north anct sonth. Wh atso model cycoics that form at 5 latitude both north and somin of the colator Fig. 1a shows crak patterns assuming a net westward component of prop

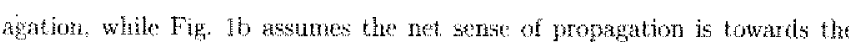
east. The eracking patterne depend on the rate of erack propayation and the assumed ice strength values (the tension required to start and maint ain couck propagationy. Here we we parameters similat to those infered from titcing yciods in the southert hemisphere (Hurford et at, 2007). Specifically, the

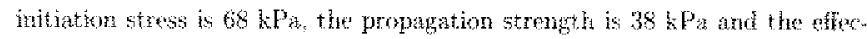
tiwe propagation speed is $4.8 \mathrm{~km} / \mathrm{hr}$. The crack maps in Fig 1 are ideaized. of wurse because details of the lecal parameters endrolling cark propatation

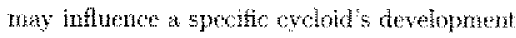

Fot comparison, Fig. 2 shows mapped cyctods act lenlly observed on Euxopa

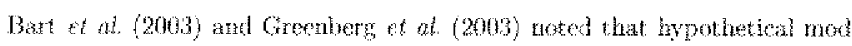
ded cyclods reproduce many of the characteristics of oberwed cylods: (1) The long eastwest trending cychds observed th the solthem, mid-latitudes

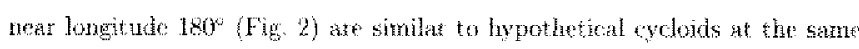
latimules, albeit not the sane longtudes (Fig lakb). In fact, these inchude the

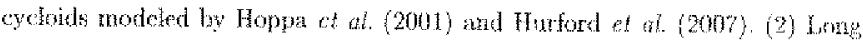

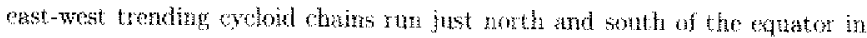

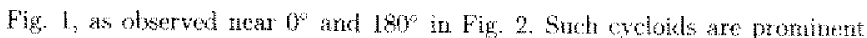

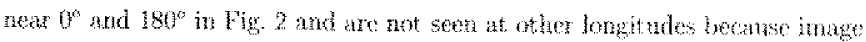

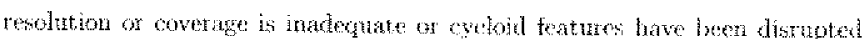

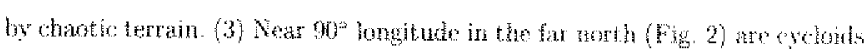

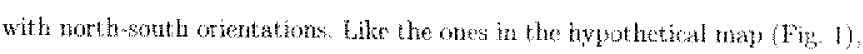
they terd to be relatively short and ure located far from the equator. (4) The?

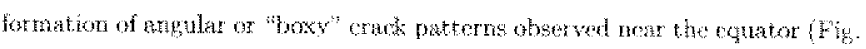
2) is similar to the model cracks in Fig. 1 in this region. These elserwel "boxy"

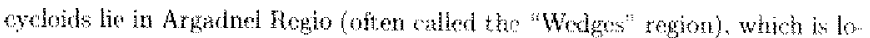

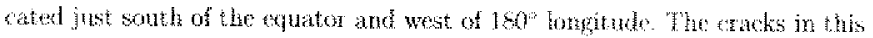
region, besides demonstwhing the boxy tyckid shapes. are often tilated mo wedge shapes. Sintar crack pattern dianetricaly opposite (in the not hera.

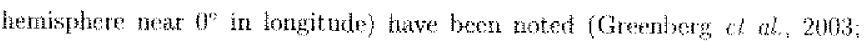

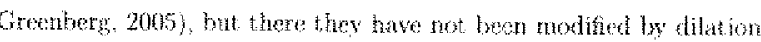

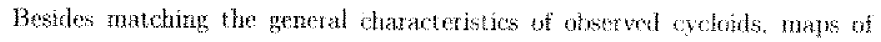

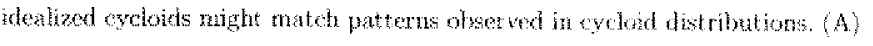

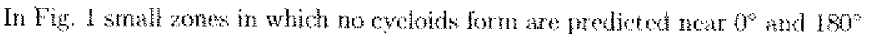

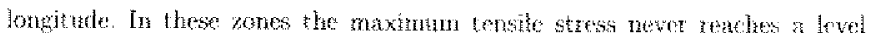
hist encugh to initiate crad formation, thrs bo cyodods origitate from these

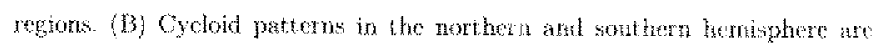

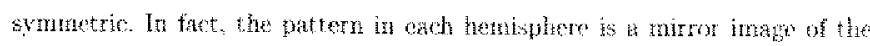
othm, reflected about the rator. 
eling cycloids with the inchision of non-5indironons rotation still protues

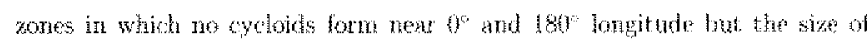
these zone increase and thein cences shift eastwart from $180^{\circ}$. Howewer, whil

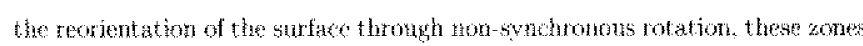

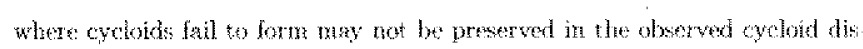

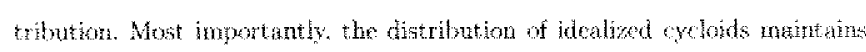
the symonetry betwers the northern and southern henisphere. Since ddealietd

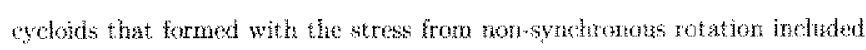

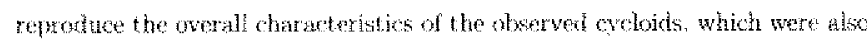

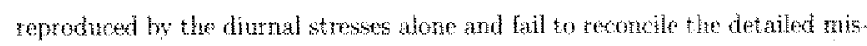
mated betwen the dealized and obgered distrinution. we will exelude the

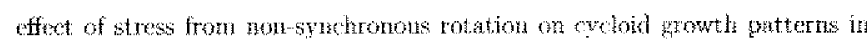
this paper.

Similarly. a saudl anowat of reotentation ty polat warder may acount for

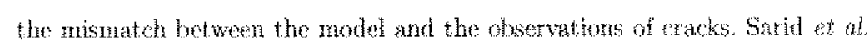
(2002) found a mismatch betweets the motel of strike-sip displarement and onscrwations strike-stip displarenent, which they antributed to polne wander of Europa se shell. However polar wander of the type they describe wonld have shifted the Argadnel hegio wegon north after its formation, inplying that it formed even further south of its carrent loctation, entancing the asymuetsy ators the equitor.

In summary, the main disagrement is that the oberrwations fo not fit the prelinted symmetry across the expatot: Cychids that cuss the equator are not symmetrical, and the "boxy" racks just wese of $180^{\circ}$ are south of the equator, while those just west of 0 are noth of the equator.

\section{Obliquity and Cycloid Modeling}

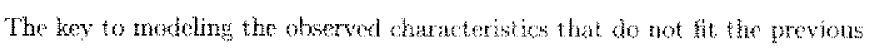

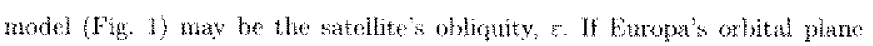

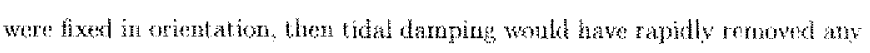
inilial oblicuity (Peale, 1974: Gladman ot at, 1996). However, the of bt plane is not fixed. but preceses about an axis very clase to Jupter's spin axis. This presesion is minly caused by torques from hupiter's oblate tigure hut atse has contrhutions from interactions with Io, Canymede, and Calisto (timate. 19981 .

As a result of the orbital preession, the configuration to which the spin polo

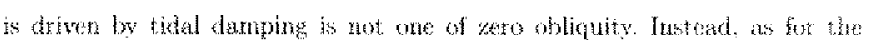

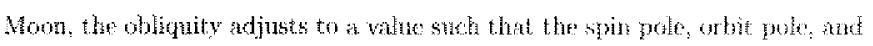

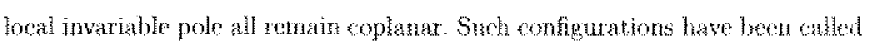
generaliaed Casins states (Colombo, 1966, Peale 1969: Wad, 1975), becuse they are similar to fethavion of the Mon, as fiest entmetated by C.D. Cassing in 1693

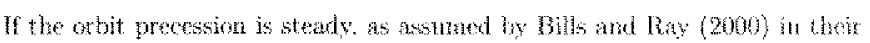

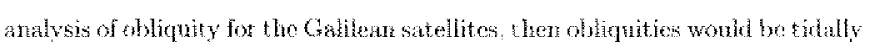

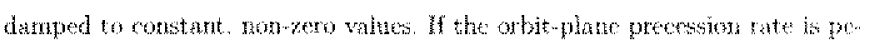

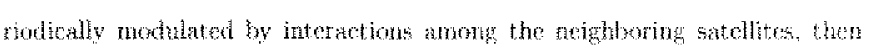
the tidaly damped obliquitios will correspondingly huctuate (Wan and do

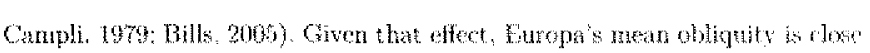
to $0.1^{\circ}$, ant oseillates by rughely $10 \%$ with domitant periods of decudes to

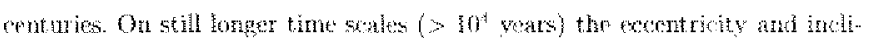


clanges in a and $\theta$ while the obliquity catuses changes only in $b$. Fupiter's angu lar postion whth respect to a fixed loeation abowe Eftopa's surfaxt oseilates

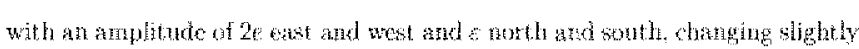

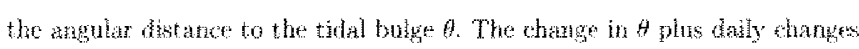

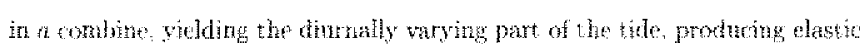
stress on the surface (Sex Appendix A)

For a witer-icx crust, following Hoppa of al. (1909), 2001) we ase the con-

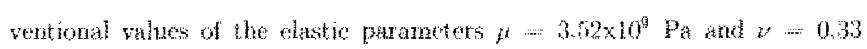
(Gatiman at at., 1983), and assume a tidal respotse given by $h_{2}=1275$. wheh coresponds to a finmal tidal amplitude of thanges in the radias of

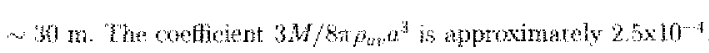

To simulate the formation of a cyolodal crack at a riven location, our molel also requires walues fer the effective wate of crak phopagation, which largery govens lerigth and curvature of the arcs: the sense (eastward or westward) of the propagation, whind detemines the direction of curvature of each are the

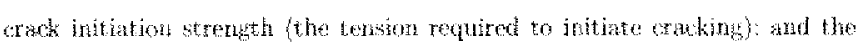
erak propagation strength (the tension helow which the onek propagation

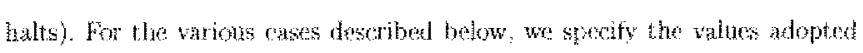
for ench of these parancters.

\section{Effects of Obliquity on Cycloids}

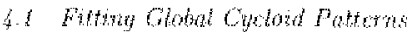

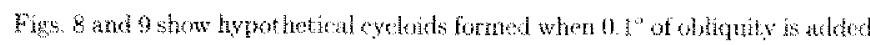

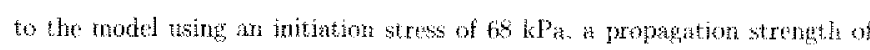

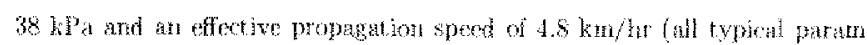
eter choices that give geterally monabo agrement with obstrwd cholold shanc). Figs 8 and 9 assime westwrot and eastward gropagation. respece tively. As shown in the separate parts of Fis. 8 and 9 the pet tern depend on where in the orbit, relative to perifow, Jupiter croses buropat in tquator

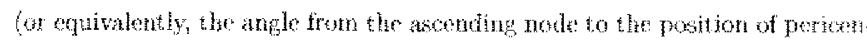
ter, known in celestial wechanes as angument of pertonter, w). Fot example,

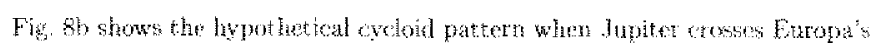

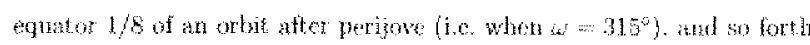

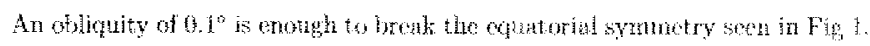
For example, in Fig sa and Fig ga. when the atgunwat of perienter somo

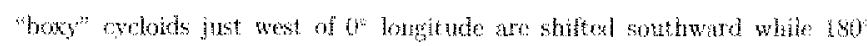

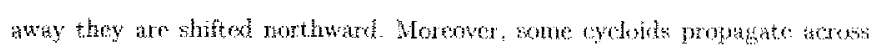
the equation

Depending on the argumon of periecenter. $\omega$, the shift in the hepothetical

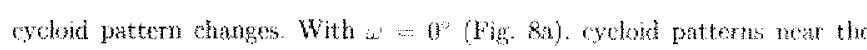

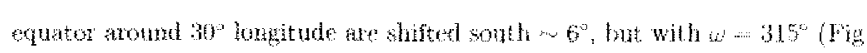

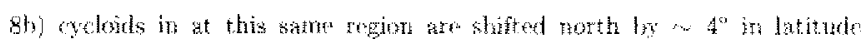

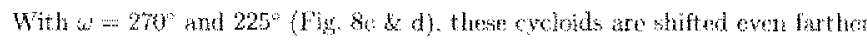




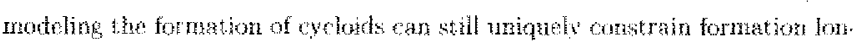
git teles. As forng as the tocation of crolods have been mowed in innpitude onl since ther formation, preserving their formation orientations, hits are micue is statistically significant

\section{Discussion}

We have shown the efects of oblinuty on the formation of hyorthetical in doids on Europa. Obliquity introbluces a component of stress due to the daly

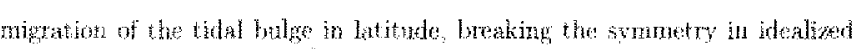

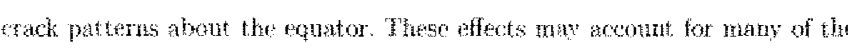

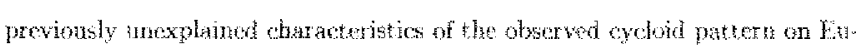

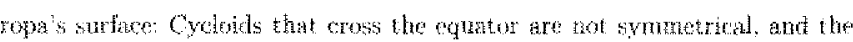
"lowy" andk just west of $180^{\circ}$ are south of the extator, while those just west ut 0 are nortit of the equator.

Adding oblinuty resplts in syololds propagating acress the ranator without changing then eastwend of westwat sense of prongation, now explaining how such oberned oyloirls can form. The modd now predies long chans of

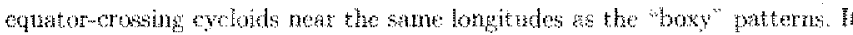
is, in fact, the romth-sonth shifting of these regions that give rise to the cockids that cros the exuator. Observations of equator crossing cyctods math suet foncentratens, wear the Argadnel Regio region and 180 in lengitude awn

"Bory" or angular cyclods resemble the olservex erack patteru in the Ar-

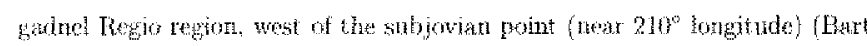

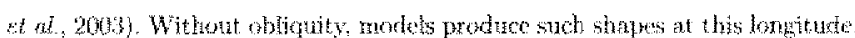

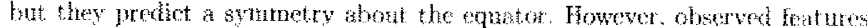
are concentated sonth of the equator and centered aromen is fartude of go's

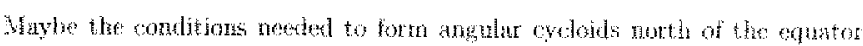

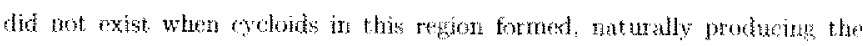

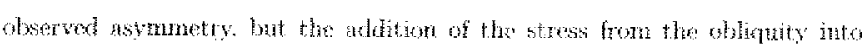
Whe radel of cyetwid formation lewds to ste asymnetry about the equator

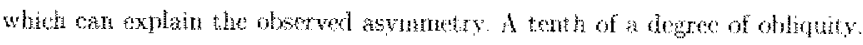
the anount estinsted by finls $\{2005\}$, is adequate to shift the center of the

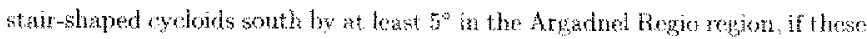

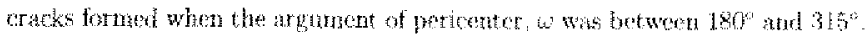

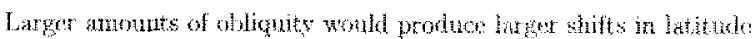

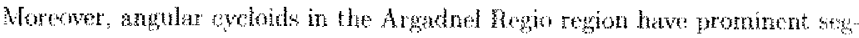
ments witl orientations that are aorth-enst/south-west or north-west/folth-

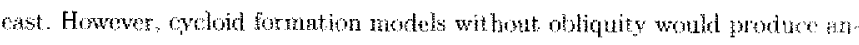

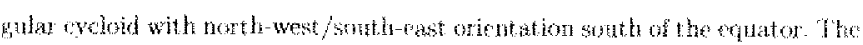

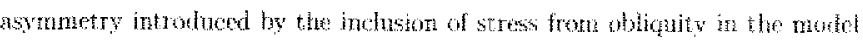

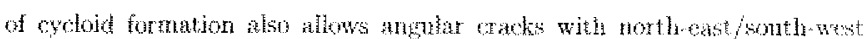

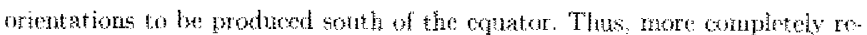

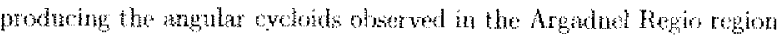

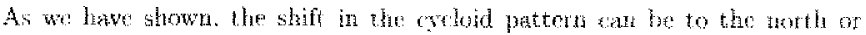
the soath depending on when in the obit Jnpiter crosses louropa's rquator. Formation of the croxk pattern in the Argarnet Rego region, heing sonth of

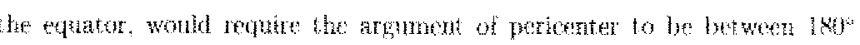

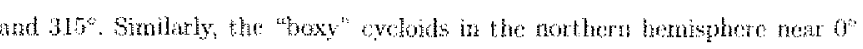

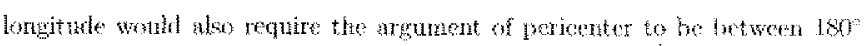

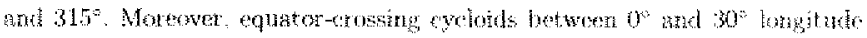




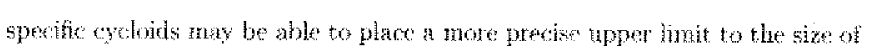
Europa's oblifuity (Surid et all, 2006).

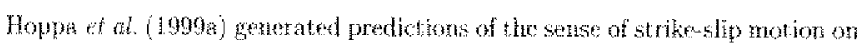
Europa's surface (i.e. left-hatenal versus rightatiateral). using the surface strebs due to diumal warations in stress produced by Europa's eecutricity. Wn otder to coupare Hoppas model to obkerwations, Sarid ef al (2002) produced mays of the observed strikeslip motion sten along Enophn ridges, and at tributed misnateth botwen the model and observatiogs to polar wander. That work

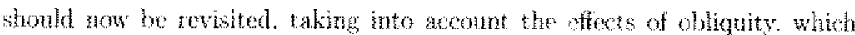
may be an alternative way to mateh the nodel and ofservations.

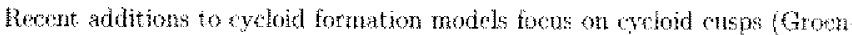
lees and kothenhom, 2008). In these nudels hertual and shear stresses are resolved onto the tip of the colotal ack white it renains dommant. Sheat notion at a critical point in the orbit leads to the fomation of at talcrach whith propugutes away from the cusp to become the next are in the cycond chain. Casy angles with he affected by the ratio of thear to urmal stres neetef to poduce the next areate segrnent and will subty affect chatacterstics of the codoid. However, these additions can not explain the formation of equator (russing cyctoids (Fig 5).

\section{Conclusions}

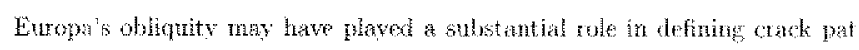
tems. The observed north-5ath asymmetry of cyctods mat be adence for the smal but finite ondiquaty of Europa predicted by Bills (2005\}. Obliquts

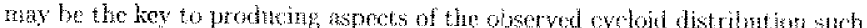

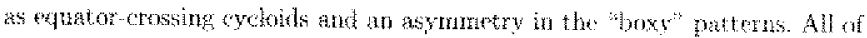
these inprowements of the fit between observation and theory settu to requin

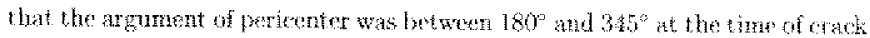

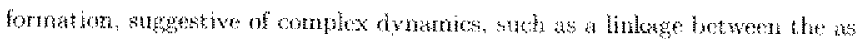

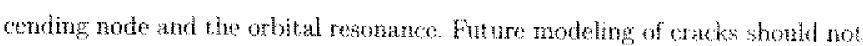
assume that the ohliquity is zero or has no chect on textonic formetion: While

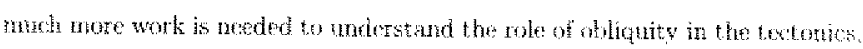

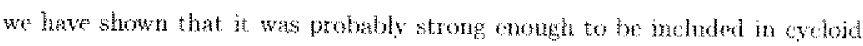
and stress models.

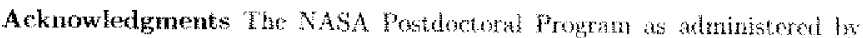
the Oak Ridge Associated Uxivetsities supported this work. We would like to

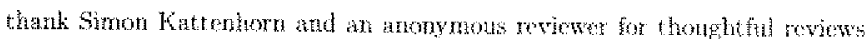
that helper inaprose this paper,

\section{References}

Bart, G. D. R. Grenbers and G. V. Fopla 2013. Cycloks am Wedges:

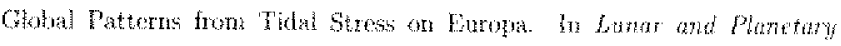
Tatitute Conferene Abstrats pe 1396.

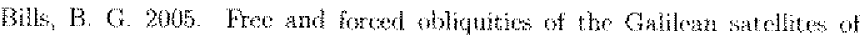
Jupiter. Icamus 175,23344 \%

Bills B. G, aud R. D. Thay 2000. Galilen satellite onhquites. JGR 105. $29277-29282$

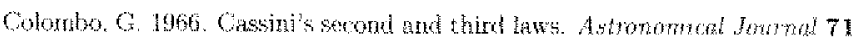
891 


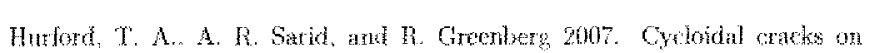
Euopa: Thiproved wodeling and non-sychonons rotation implications. Icarts $186,218,239$.

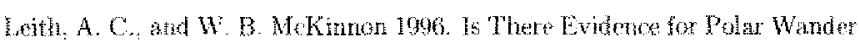
on Elaropra? Iamik 120. 387 . 398.

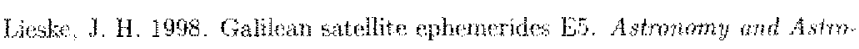
phystes Supplement $129.205,217$

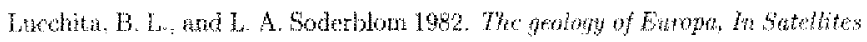

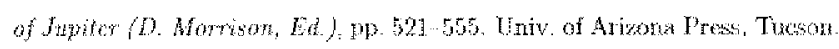
Malin, M. C. and D. C. Pitri 1986. Btwom In Satelites G A. Butry and

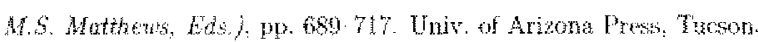

Mckwen. A. S. 1986. Tidal reorientation and the fraturing of dujita's mont Europa. Natary 321, 49 \$1.

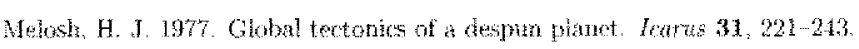
Peale, S. J. 1969. Gomalizod Cassin's Laws. Astronminal Journal 74, 483. Peale, S. 3. 1974. Possible nistonie of the obliquity of Mereury. Astromomictol Journat $79.72 \%$

Sarid, A. R, R. Grenberg. G. V. Hoppa D. M. Brown. and 1'. Geissior

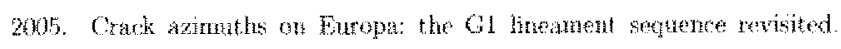
Icarne $173,469 \cdot 479$

Sarid, A. B, R. Grembers, G. V. Hoppa, T. A. Harforel, 18. W. Thtts, and P. Geissler 2002 . Polar Whater and Surface Convergence of Finope's lee

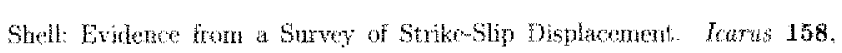
$24+4$

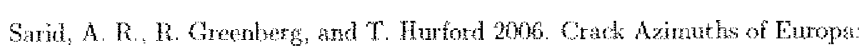

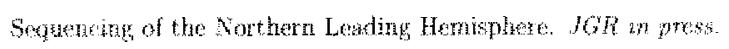

Sarid, A. M. T. Hurford, E. M. Huff, and M. Matiga 2007 . Tidaly-driven
Fractures on Enropa: Historical Overview and New Medeling Tednicues ACU Fot Weting Abstroct., Bl242.

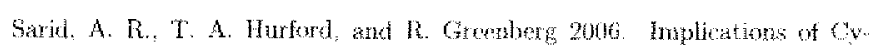

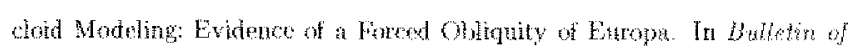

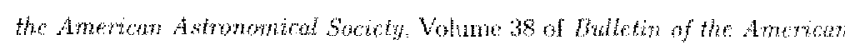
Astrenomical Sorietil pp. 612

Snith, B. A., L. A. Sodtbom, R. Beebe I. Boye G. Brigge, M. Carr. S A.

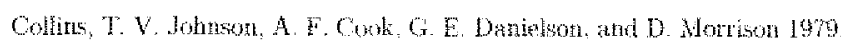

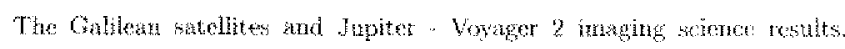
Sckence 206, 927950

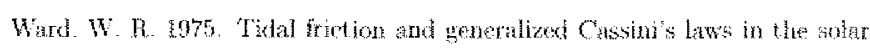
sysent. Astrotomited Jow Thal $80,64 \cdot 70$.

Ward, W. R. and W. M. de Campli 1979. Comments on the Venus rotat tion pole. Art Letters 230. L117 L121.

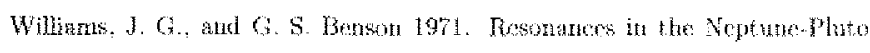
Systen. Astrotomicat Jowntal $76,167 \quad 176$ 


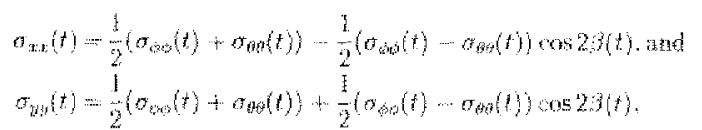

$$
\begin{aligned}
& \sigma_{\mathrm{sy}}(t)=\sigma_{y+1}(t)=\frac{1}{2}\left(\sigma_{\phi \%}(t) \cdots \sigma_{m}(t)\right) \sin 23(t)
\end{aligned}
$$

where the anges $3(t)$ between rorth and the ofolt) direction, which deserile the orentation of the grincipal stresese and is giwn by

$$
\partial(t)=\cos ^{-1}\left[\frac{\sin (x \sin (m t-\omega)\}-\sin \delta \cos \theta(t)}{\cos \theta \sin \theta(t)}\right]
$$

With the formulation of a and o(t) in similar reference fyanus, the churnat stres, $\sigma^{D}$, can now be evaluated. It is aten onvenient to expees the diutnal stress tensor in teans of the princopal stresses, suth that shent stresses are zero,

$$
\sigma^{D} \ldots\left|\begin{array}{ll}
\sigma_{1}^{b} & 0 \\
0 & \sigma_{2}^{b}
\end{array}\right|
$$

The principal strenses are

$$
\sigma_{1}^{D}=\sigma_{t x}^{D} \cos ^{2} \gamma_{D}+\phi_{u,}^{D} \sin ^{2} \gamma_{D}+\alpha_{\eta_{0}}^{D} \sin 2 \gamma_{b}
$$

and

$$
\sigma_{z}^{D}=\sigma_{x+}^{D} \sin ^{2} \gamma_{D}+\sigma_{y y}^{D} \cos ^{2} \gamma_{D}-\sigma_{2 y}^{B H} \sin 2 \gamma_{D}
$$

where $y$ describss the orientation of the principal stress nxis and is given by.

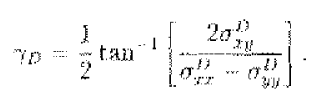

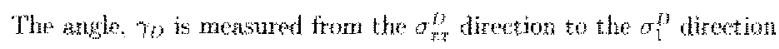

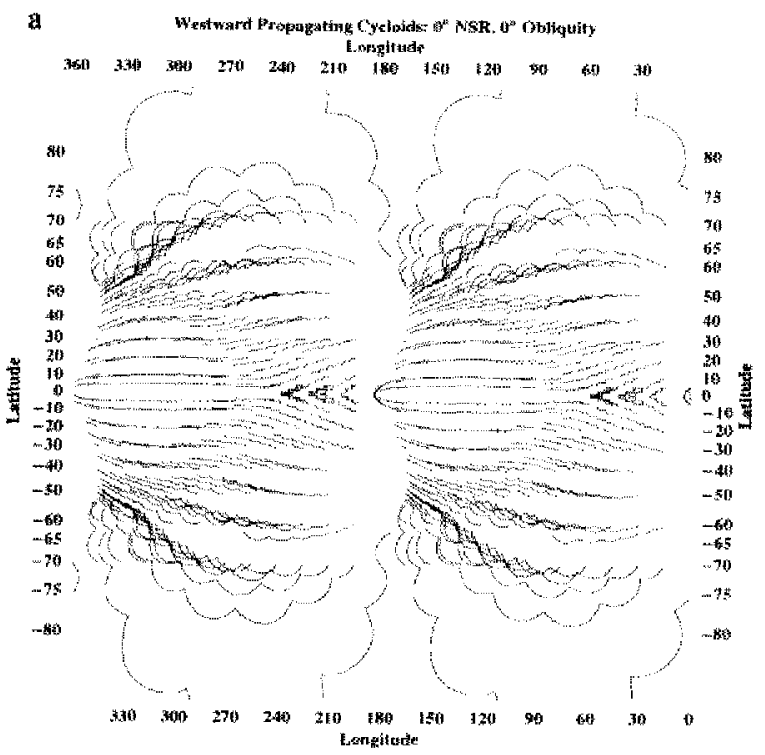

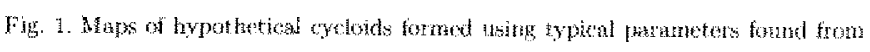

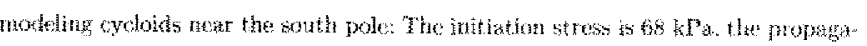

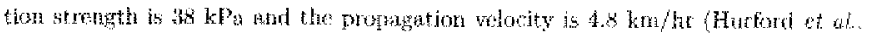

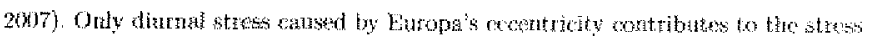

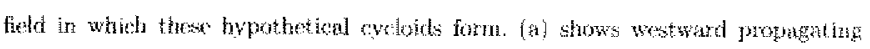

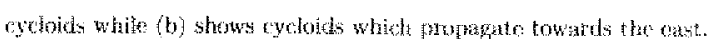




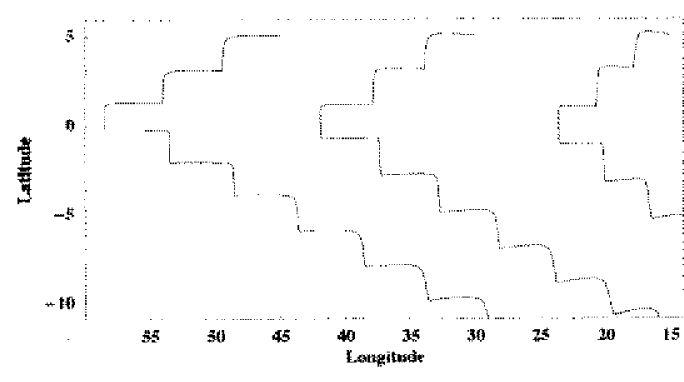

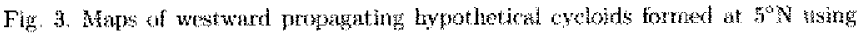

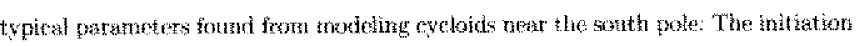
stres ss $68 \mathrm{kPa}$, the prophapaticn strength is $38 \mathrm{kPa}$ and the propagation velority is

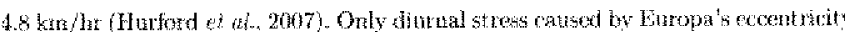
exntributes to the stress fedth in whicts these hypothetiol cycloids form.

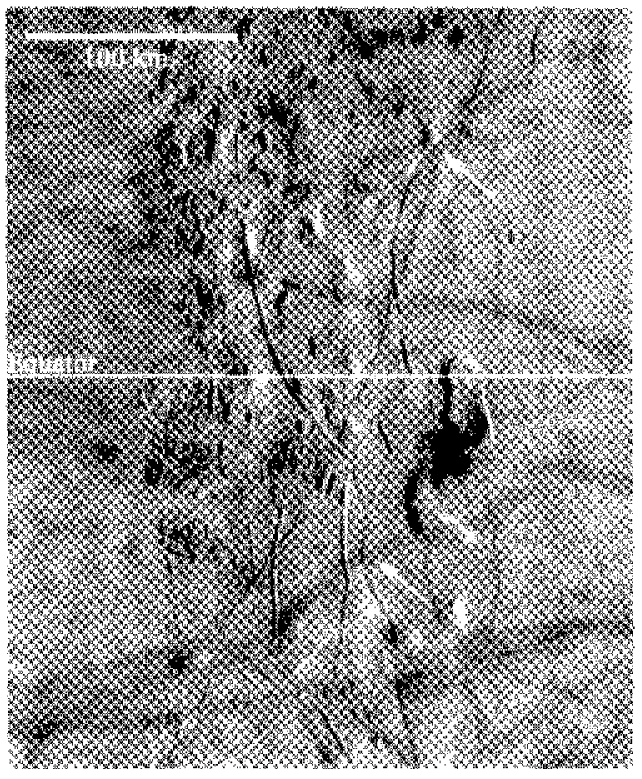

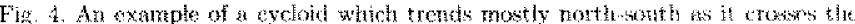

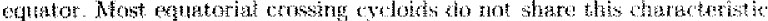




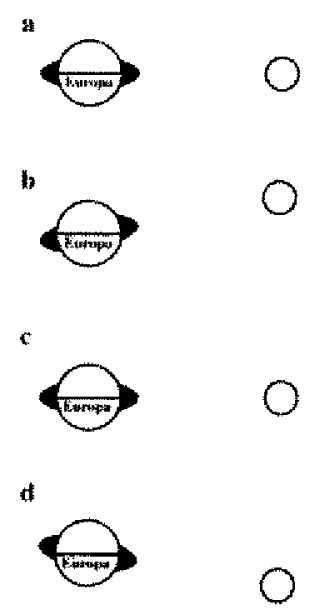

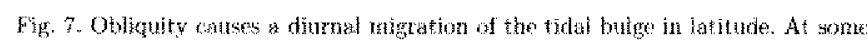

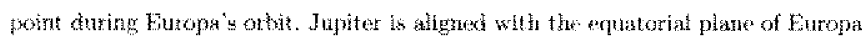

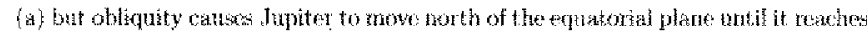
its farthest northrn point $I / 4$ an orbit later (b). Then Jupiter rawes wath watil

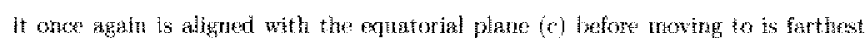
sosthern point $3 / 4$ of an onbit leter $\{d\}$

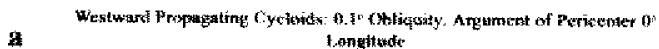

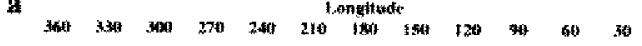

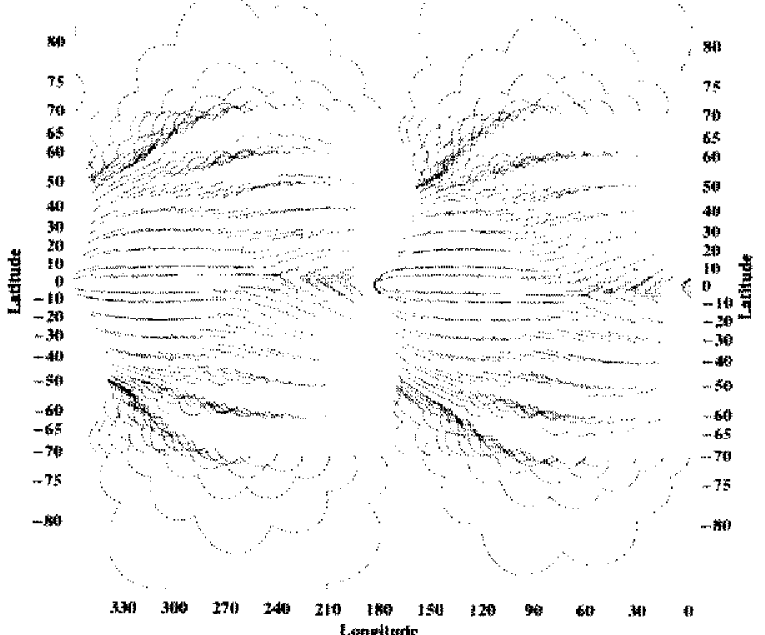

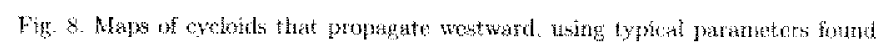

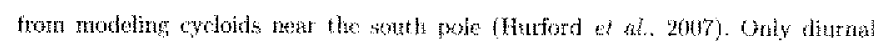

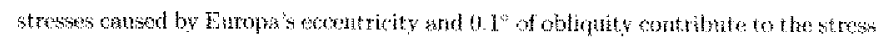

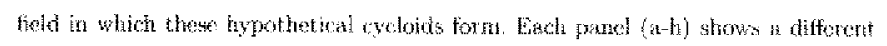

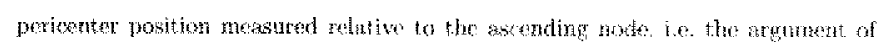
pericenter, in increments of 15 ". 


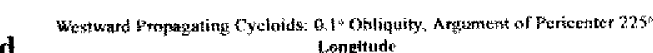

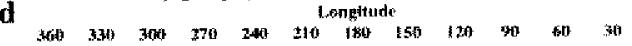

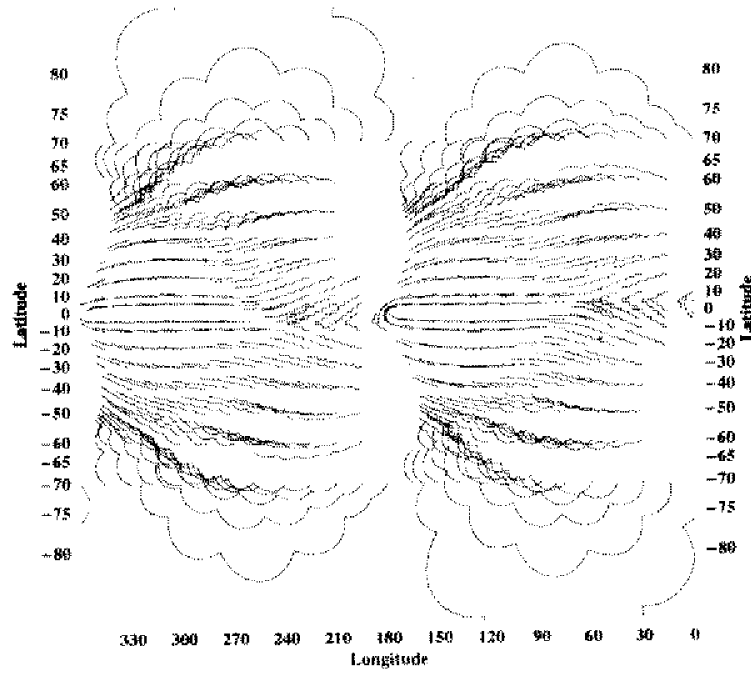

Fig. 8. (Comilywed $)$

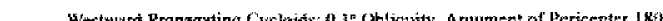

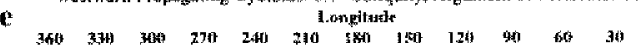

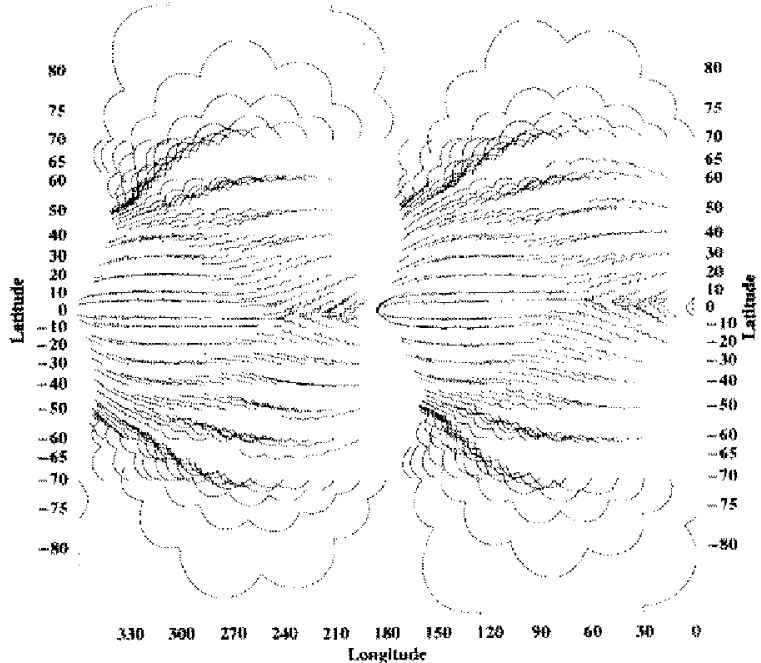

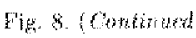




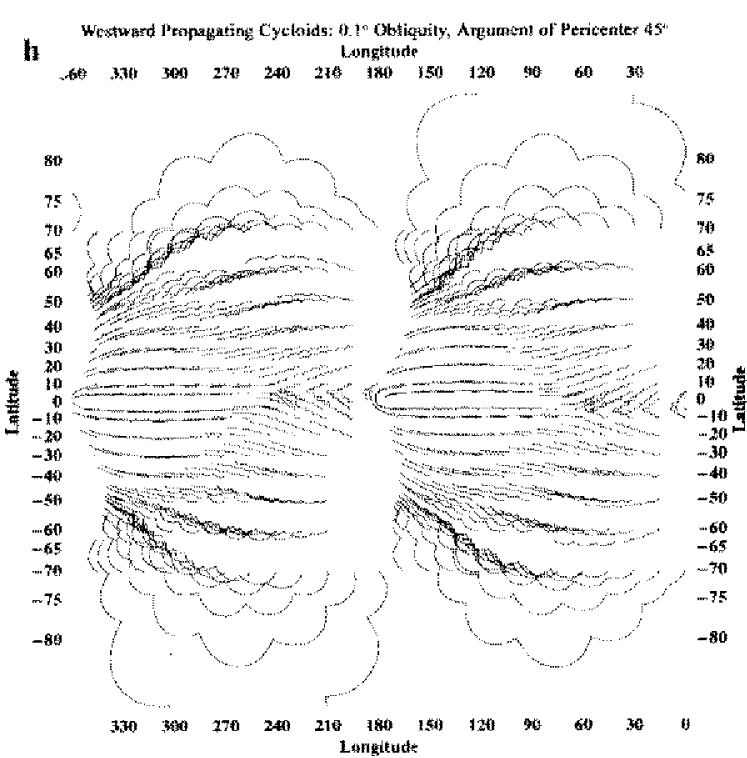

Fug, \&. (Continused)

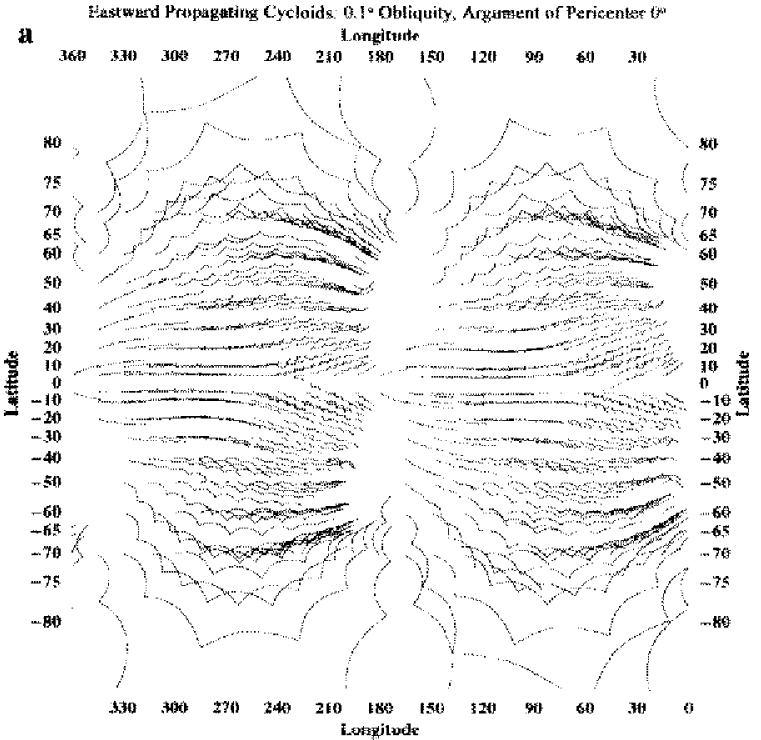

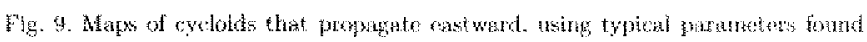

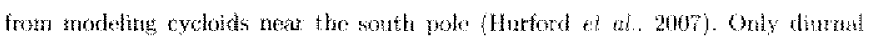

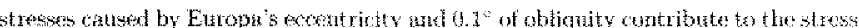

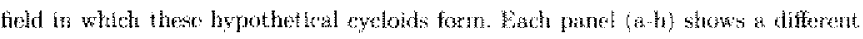

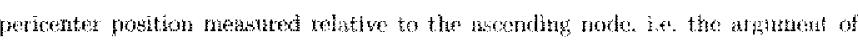
perienter. in inerements of ts 


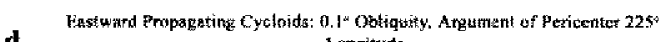

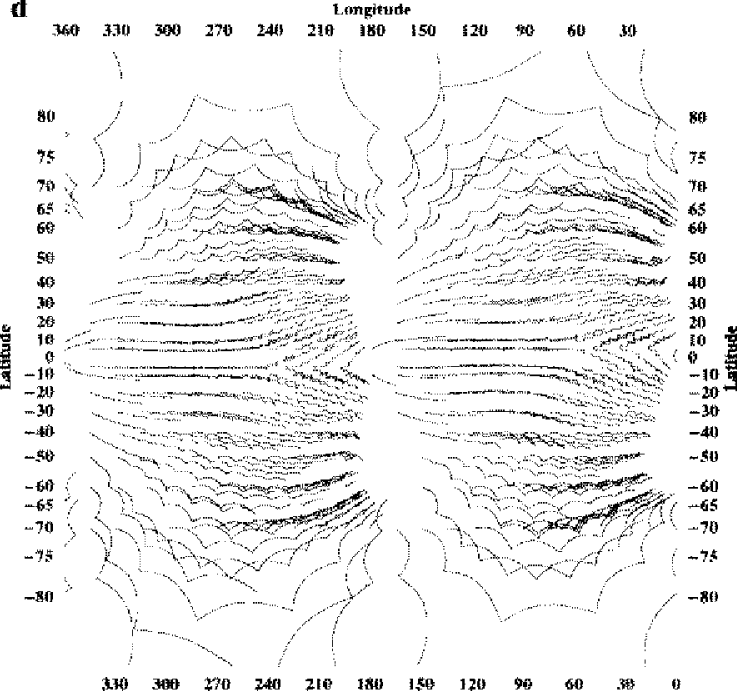

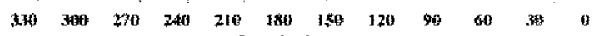

tongiatur

Fip. 9. (Contivitued

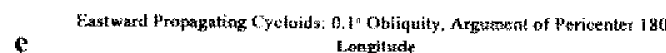

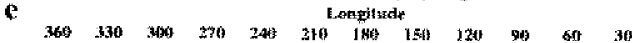

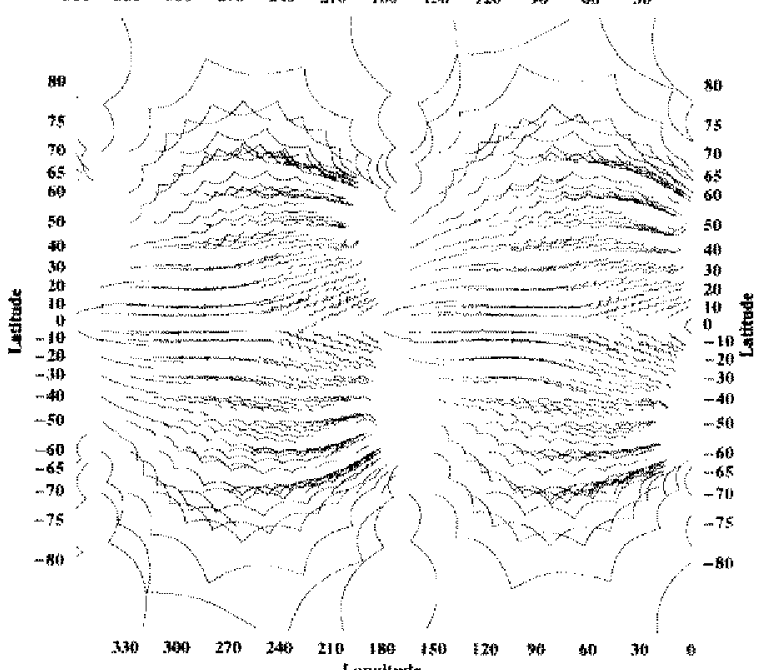

tornturde

Fis. 9. (Coxdintuet) 


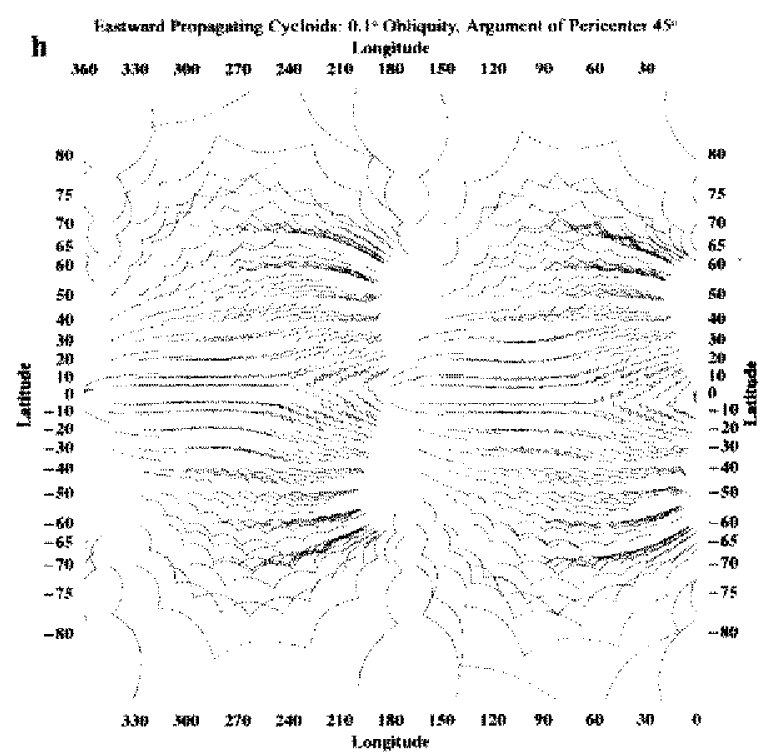

Fig. 9. (Contimuet)
Fit with $70^{\circ}$ longitude shift, $0.25^{\circ}$ obliquity, $\omega=345^{\circ}$

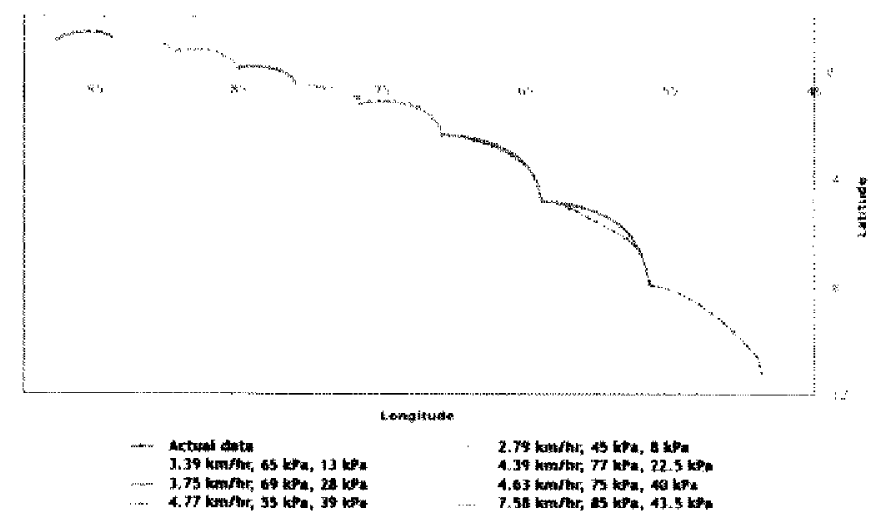

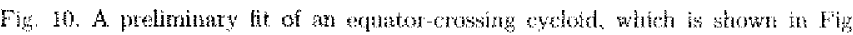

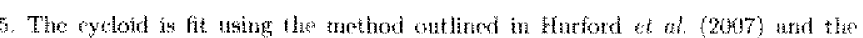

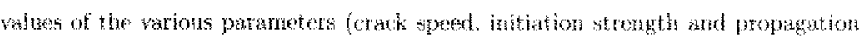
stewgth) are listed betow the figure 